TI 2015-011/VIII

Tinbergen Institute Discussion Paper

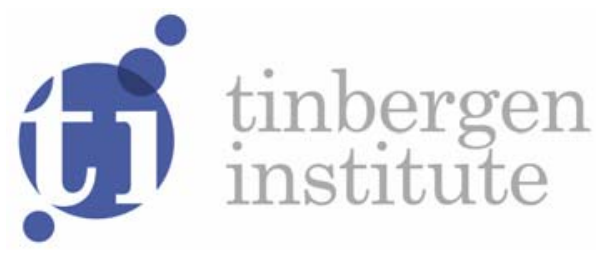

\title{
Does Public Transit reduce Car Travel Externalities?
}

\author{
Martin W. Adler \\ Jos N. van Ommeren
}

Faculty of Economics and Business Administration, VU University Amsterdam, the Netherlands. 
Tinbergen Institute is the graduate school and research institute in economics of Erasmus University Rotterdam, the University of Amsterdam and VU University Amsterdam.

More TI discussion papers can be downloaded at http://www.tinbergen.nl

Tinbergen Institute has two locations:

Tinbergen Institute Amsterdam

Gustav Mahlerplein 117

1082 MS Amsterdam

The Netherlands

Tel.: +31(0)205251600

Tinbergen Institute Rotterdam

Burg. Oudlaan 50

3062 PA Rotterdam

The Netherlands

Tel.: +31(0)10 4088900

Fax: $+31(0) 104089031$

Duisenberg school of finance is a collaboration of the Dutch financial sector and universities, with the ambition to support innovative research and offer top quality academic education in core areas of finance.

DSF research papers can be downloaded at: http://www.dsf.nl/

Duisenberg school of finance

Gustav Mahlerplein 117

1082 MS Amsterdam

The Netherlands

Tel.: +31(0)20 5258579 


\title{
Does public transit reduce car travel externalities? Quasi-natural experiments' evidence from transit strikes
}

\author{
Discussion Paper \\ Martin W. Adler and Jos N. van Ommeren \\ VU University Amsterdam and Tinbergen Institute
}

January 202015

\begin{abstract}
One of the main unanswered questions in the field of urban economics is to which extent subsidies to public transit are justified. We examine one of the main benefits of public transit, a reduction in car congestion externalities, the so-called congestion relief benefit, using quasinatural experimental data on citywide public transit strikes for Rotterdam. On weekdays, a strike induces car speed to decrease only marginally on the highway ring road (by 3 percent) but substantially on inner city roads (by 10 percent). During rush hour, the strike effect is much more pronounced. The congestion relief benefit is substantial, equivalent to about half of the public transit subsidy. We demonstrate that during weekends, car speed does not change noticeable due to strikes. Further, we show that public transit strikes induce similar increases in number of cyclists as number of car travelers suggesting that bicycling-promoting policies to reduce car congestion externalities might be attractive.
\end{abstract}

Keywords: transit subsidies, public transit, traffic congestion, congestion relief benefit, strike JEL H76, J52, L92, R41

Acknowledgments: We would like to commemorate our colleague Piet Rietveld who was involved in the early stages of this paper but who passed away on $1^{\text {st }}$ of November, 2013. This paper is funded by Kennis voor Klimaat. We thank Taoufik Bakri from TNO Delft, Jos Streng and Roel Rijthoven from Rotterdam municipality for support in data acquisition and constructive remarks. Furthermore, we thank Hugo Silva and the seminar audiences of the Amsterdam Tinbergen Institute, Toulouse ITEA 2014 and St Petersburg ERSA 2014 conference for useful comments. Jos van Ommeren is a fellow of the Tinbergen Institute. 


\section{Introduction}

The provision of public transit is thought to reduce travel time losses that are due to car congestion. For this reason, it is economically justified to subsidise public transit from a welfare perspective as it creates a congestion-relief benefit. ${ }^{1}$ Note that car use and public transit use are not perfect substitutes, so subsidies to public transit provision might be interpreted as a second-best policy. It is then important to realise that public transit provision is not the only policy alternative for policymakers to address negative car externalities (Basso and Silva, 2014). For example, we will provide evidence that bicycling-promoting policies might be another cost-effective way to realise congestion-relief benefits.

The main goal of this paper is to quantify the congestion-relief benefit of public transit for Rotterdam by analysing car speed during public transit strikes. ${ }^{2}$ Arguably, strikes can be interpreted as exogenous transit supply shocks and therefore as a quasi-natural experiment as argued by a series of studies (Crain and Flynn, 1975; Van Exel and Rietveld, 2001; Aftabuzzaman et al., 2010; Marsden and Docherty, 2013). ${ }^{3}$ We are aware of two other papers that use the same methodology. Lo and Hall (2006) and, more recently, Anderson (2014) both analyse the effect of (the same) single transit strike lasting 35 days on highway speed for Los Angeles. Anderson (2014) finds a substantial congestion relief benefit with a decrease in time delays experienced by car drivers of 0.12 minutes per kilometer traveled. ${ }^{4}$ It is unknown to what extent this result can be generalised to cities where the share of public transit use is much higher or to cities where bicycle use might be a viable alternative. ${ }^{5}$

Our analysis differs from Anderson (2014) and Lo and Hall (2006) in a number of ways. First, we focus on a city, Rotterdam in the Netherlands, which, as we will document, is only mildly congested. Second, we analyse the effect of multiple strikes of various public

\footnotetext{
${ }^{1}$ The other main reasons for public transit provision are that car travel is underpriced and that public transit's average costs are lower than its marginal costs because of the presence of fixed cost and the 'Mohring (1972) effect'. Car congestion is the main externality of car travel in addition to air pollution and road accidents.

${ }^{2} \mathrm{Up}$ to the 90 's, strikes received a lot of attention in the economics literature which shows that the majority of strike days are public sector strikes. For example, 86\% of UK strike days are in this sector (ONS, 2014). In many countries, a large share of public sector strikes are public transit firms, because these firms have market power, and are unionized, which are both key strike determinants.

${ }^{3}$ Information about the congestion-relief benefit of public transit is essential for a welfare analysis of public transit provision such as the study by Parry and Small (2009) which assumes that public transit provision reduces car travel time by 0.04 minutes per kilometer traveled, substantially less than the results indicated by Anderson (2014). Nevertheless, similar to Nelson et. al (2007), they conclude that subsidies up to $90 \%$ of operating cost would be welfare improving. Also Proost and Van Dender (2008) and Basso and Silva (2014) indicate that during peak hours, it would be beneficial if subsidies cover $50 \%$ up to $100 \%$ of operating cost.

${ }^{4}$ Lo and Hall (2006) report speed reductions by $20 \%$ to $40 \%$. However, an earlier strike in the year 2000, not analysed by Lo and Hall (2006) and Anderson (2014) seems to decrease speed by only 5\% (The Economist, 2000).

${ }^{5}$ As is well known, in comparison to Los Angeles, almost all European and Asian cities provide levels of public transit that are an order of magnitude higher. Because it is likely that the congestion relief benefit is a concave function of the level of transit provision, the marginal benefit might be lower in these cities.
} 
transit modes (e.g. bus, light rail) that are citywide. Third, we examine the strike effect on car speed (and flow) both for the highway ring road as well as within the inner-city of Rotterdam. Fourth, we examine to what extent transit strikes induce public transit travelers to switch into cycling. The latter is particularly relevant, because, as argued by Basso and Silva (2014), public transit subsidies should be evaluated according to other urban policies with a similar aim, such as congestion pricing and bicycling-promoting policies. Finally, by examining heterogeneity in the effects of strikes, we are able to improve our understanding when the public transit relief benefit is particularly pronounced. For example, as one may expect, we find a particularly strong effect of strikes on car speed during weekday rush hours (but no clear effect during weekends and outside rush hours). In addition, our results suggest that the speed effects of strikes that last a few hours are similar to full-day strikes indicating that a continuous supply of public transit during the day is essential for travelers.

We show that the congestion relief impact in Rotterdam is by a factor ten larger for inner city roads than for highway ring roads. For the latter we found a several times smaller effect than Anderson (2014). It turns out that the congestion relief benefit of public transit for Rotterdam is substantial, and about $50 \%$ of the current subsidy level. This result is particularly noteworthy as we focus on what can be considered an uncongested city. This suggests that subsidies to public transit are welfare improving, even for cities that exhibit low congestion levels.

\section{Data and descriptives}

\subsection{Introduction}

We analyse public transit strikes for the period 2001 to 2011 for Rotterdam, a Dutch city with a metropolitan population of about 1.2 million inhabitants. Public transit use is substantial: $21 \%$ of residents and $25 \%$ of commuters use it each day. Car ownership is low: only $57 \%$ of adults belong to a car-owning household, but the proportion of commuters who travel by car is representative for the Netherlands: about half of the Rotterdam commuters travel by car (De Vries, 2013). Average speed for a commuter car trip is about $30 \mathrm{~km} / \mathrm{h}$ (Savelberg, 2013). As will be documented later on, in Rotterdam there is little car congestion, as speed within the city, as well as on the highway ring road is close to the legal maximum speed limit. Also, as is well known, in the Netherlands, the use of the bicycle is quite common. In line with this, the large majority of Rotterdam residents own a bicycle. We emphasise however that bicycle use 
is low from a Dutch perspective: only 14 percent of commuters use it on a daily basis (by comparison, in Amsterdam this percentage is more than double). ${ }^{6}$

There is one public transit operator RET which provides non-regional bus, tram, metro and light rail connections within the Rotterdam metropolitan area. Regional bus connections are provided by another (private) company. ${ }^{7}$ Within Rotterdam, many roads have separate bicycle paths, which allows us to measure bicycle use.

We will analyse hourly information about bicycle flow, car flow and car speed for the inner city and about car flow and car speed for the highway ring road (see subsections 2.3 and 2.4) and relate this to the occurrence of strikes (see subsection 2.2). ${ }^{8}$

\subsection{Strikes}

Information on public transit strikes is obtained from the Rotterdam municipality, the public transit operator, newspapers and Internet search. We observe 16 public transit strikes between 2001 and 2011. Table 1 lists these strikes by mode, type, date, time and additional information, such as whether the strikes were announced. We focus on 13 citywide transit strikes, defined as strikes that affect all non-regional buses, trams and metro within the city, but also consider two national rail strikes and one regional bus strike. ${ }^{9}$ Regional buses also operate on routes inside the city, but during citywide strikes do not stop within the city (in order not to break the strike).

About half of the citywide strikes last a full day. The other half usually ends after four to five hours, and will be labeled partial-day strikes. The majority of strikes include rush hours, defined to be between 7am-9am and 4pm-6pm on weekdays. All strikes end within 24 hours after commencement except for one regional bus strike that involves strike disruptions on three consecutive days within Rotterdam. For only one strike (in October 2014), both national rail and citywide transit strikes occurred on the same day. Importantly, all strikes, except two, were announced (also in national media) well in advance. ${ }^{10}$

Three strikes were first announced and later canceled. We will use these canceled strikes as placebo strikes. Arguably, if the effect of announcements of strikes on switching

\footnotetext{
${ }^{6}$ One of the reasons for the low bicycle use in Rotterdam is that it has been rebuilt as a modern ('American') city after its destruction during the Second World War.

${ }^{7}$ Rail is supplied by semi-public rail operator, and regional bus is supplied by a private firm Connexxion.

${ }^{8}$ Information on inner city traffic is provided by Rotterdam municipality and on highway traffic by TNO.

${ }^{9}$ About one third of Dutch train users combine train use with bicycle or car use (van Goeverden and Egeter, 1993, and van der Loop, 1997), so a train strike may decrease bicycle and car use for some train travellers.

${ }^{10}$ Strike information prior to the strike is not always clear and sometimes even misleading. For example, for the $12^{\text {th }}$ of April 2011 strike, travelers were warned that services would be gradually reduced starting from 9am but actually service provision grinded to a complete halt at this time (Treinreiziger, 2011).
} 
travel mode is sufficiently small (for which we will provide evidence), then these canceled strikes can indeed be interpreted as placebo strikes. ${ }^{11}$

Table 1 - Public transit strikes Rotterdam, 2000-2011

\begin{tabular}{|c|c|c|c|c|}
\hline Type & Date & & Time & Information \\
\hline \multicolumn{5}{|l|}{ Citywide strikes } \\
\hline & Wednesday & 08-10-2003 & $10 \mathrm{am}$ to $2 \mathrm{pm}$ & \\
\hline & Thursday & $14-10-2004$ & Full-day & Also rail \\
\hline & Wednesday & 29-06-2005 & Full-day & \\
\hline & Monday & 04-09-2006 & $12 \mathrm{am}$ to $1 \mathrm{pm}$ & No metro strike, unannounced \\
\hline & Monday & $18-09-2006$ & $8 \mathrm{am}$ to $1 \mathrm{pm}$ & Unannounced \\
\hline & Monday & 25-09-2006 & Full-day & \\
\hline & Wednesday & $15-11-2006$ & $10 \mathrm{am}$ to $4 \mathrm{pm}$ & No metro strike \\
\hline & Wednesday & $16-02-2011$ & Full-day & Reduced schedule \\
\hline & Tuesday & $12-04-2011$ & 9am to $2 \mathrm{pm}$ & \\
\hline & Wednesday & $11-05-2011$ & $5 a m-9 a m$ & Irregular schedule \\
\hline & Thursday & 09-06-2011 & Full-day & \\
\hline & Wednesday & 29-06-2011 & 9am to 3pm & \\
\hline & Sunday & 20-11-2011 & Full-day & \\
\hline \multicolumn{5}{|c|}{ Rail strikes (only) } \\
\hline & Thursday & $21-12-2000$ & Full-day & \\
\hline & Friday & 17-06-2005 & Full-day & \\
\hline \multicolumn{5}{|c|}{ Regional bus strike (only) } \\
\hline & Tuesday & 20-05-2008 & \multirow{3}{*}{$\begin{array}{l}9 \mathrm{am} \text { to } 4 \mathrm{pm} \text {, after } \\
7 \mathrm{pm}\end{array}$} & \\
\hline & Wednesday & 21-05-2008 & & \\
\hline & Thursday & $22-05-2008$ & & \\
\hline \multicolumn{5}{|l|}{ Placebo strikes } \\
\hline Rail strike & Monday & 02-04-2001 & No strike & Canceled \\
\hline Citywide strike & Wednesday & 06-10-2009 & No strike & Canceled \\
\hline Citywide strike & Sunday & 06-11-2011 & No strike & Canceled \\
\hline
\end{tabular}

\subsection{Inner City Traffic}

For the inner city, information on the hourly number of cars on the road and bicycle travelers on bicycle paths is collected by pneumatic tubes. We have this information for all directions at 24 locations, equally distributed over the city (see Figure A1 in the Appendix). ${ }^{12}$ For 21 out of 24 locations, there is information on either car or bicycle travel. For three locations, two bridges and a tunnel that span the river Maas, information on both car and bicycle travel is available. ${ }^{13}$ In total, we have 36 measurement directions for bicycle flow on bicycle paths and

\footnotetext{
${ }^{11}$ Cancellations occur due to legal challenges and not due to anticipated road conditions. The placebo strike in 2011 was canceled a week before, but the other two only hours before. Because we will show that announced and unannounced strikes have similar effects, it is reasonable to interpret canceled strikes as placebo strikes.

${ }^{12}$ Most locations have two directions. There are is one location with information on one direction and one location with three directions.

${ }^{13}$ The river Maas is a major waterway that divides the city into two parts. The two bridges and tunnel are the only possibility to cross within a span of $5 \mathrm{~km}$.
} 
16 for car flow (see Table A1 in Appendix). ${ }^{14}$ For two locations, so four directions, we have information on car travel speed. Although we have only four independent speed measurements, these can be thought to be representative for the speed within the whole city as previous studies indicate that within-city speed observations over different locations are strongly correlated (e.g. Arnott, 2013; Fosgerau and Small, 2013).

\section{Figure 1 - Car speed}

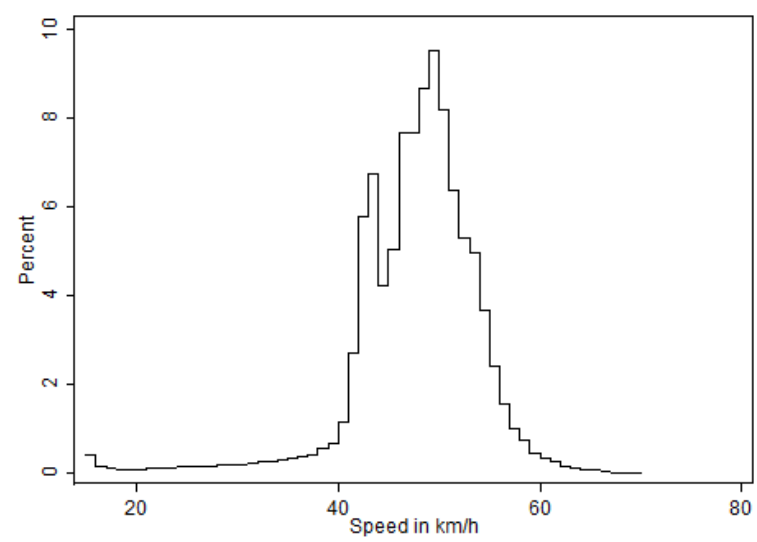

Figure 2 - Car and Bicycle flows

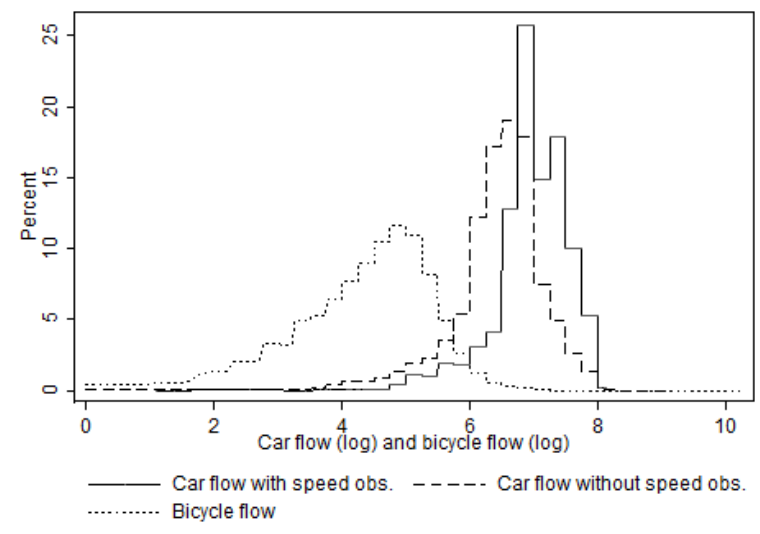

In our analysis, for a causal interpretation of the strike effect, we aim to compare transport outcomes on strike days with transport outcomes on similar non-strike days. As can been seen in Table 1, during certain periods (e.g. the summer) there were no strikes. Although this may be accidental, it is also possible that strikes were avoided during certain periods for certain reason (e.g. during the summer public transit use is lower, so a strike may be less or more desirable from the point of view of the strike organizer). Hence, we exclude four months (January, March, July and August) and three years without a strike (2002, 2007 and 2010). ${ }^{15}$ Car flow is for a few observations zero and for convenience (as we will use logs) these observations will be excluded. We focus on observations between 6am and 8pm (i.e. 14 hours). In total, we have 88,106 hourly observations of car speed, 338,782 of car flow and 719,661 of bicycle flow.

\footnotetext{
${ }^{14}$ Cycling paths are separated traffic lanes designated for bicycle travel. For most paths this includes a small share of motorized bicycles and small scooters. Negative measurement error for bicycle flow is present because only one bicycle can be recorded every 0.050 seconds. This results in downward bias of $5 \%$ to $20 \%$ for highly frequented paths (Bell and Vibbert, 1990). Hence, our estimates of strike effects on bicycle travel may be somewhat biased towards zero.

${ }^{15}$ Including these observations provides almost identical results. About $12.2 \%$ of observations are missing, as, due to malfunction and vandalism pneumatic tubes are occasionally not operating. The occurrence of missing observations is independent of the occurrence of strikes and missing observations are excluded from the analysis without introducing selection bias.
} 
Our measure of car speed is based on the proportion of vehicles that travel at a certain speed (during one hour), observed for 11 speed intervals. ${ }^{16}$ We construct hourly speed by calculating the average using the mid-speed value and the proportion of cars per interval. ${ }^{17}$ This is potentially problematic, because the lowest interval, below 31 kilometer per hour $(\mathrm{km} / \mathrm{h})$, is quite large. For this speed interval, we assume cars to drive $15 \mathrm{~km} / \mathrm{h}$, but we also make other assumptions as discussed in the sensitivity analyses. Car speed is (almost) normally distributed, see Figure 1, and locations with information on car speed have a similar car flow distribution as other locations, see Figure 2.

Table 3a - Summary statistics inner city traffic

\begin{tabular}{|c|c|c|c|c|c|c|c|c|c|}
\hline & \multicolumn{3}{|c|}{ Car speed } & \multicolumn{3}{|c|}{ Car flow } & \multicolumn{3}{|c|}{ Bicycle flow } \\
\hline & Mean & $\mathrm{SD}$ & Obs. & Mean & SD & Obs. & Mean & $\mathrm{SD}$ & Obs. \\
\hline Full-day citywide strike & 44.5 & 8.8 & 294 & 894.1 & 508.7 & 854 & 188.1 & 249.6 & 2,212 \\
\hline Rush hour & 39.7 & 10.7 & 68 & $1,090.0$ & 568.7 & 212 & 312.4 & 234.8 & 506 \\
\hline Non-rush hour & 46.0 & 7.6 & 226 & 829.3 & 470.1 & 642 & 151.6 & 242.1 & 1,702 \\
\hline Partial-day citywide strike & 45.3 & 7.3 & 348 & 911.0 & 514.9 & 992 & 179.5 & 163.3 & 2,605 \\
\hline Strike \& rush hour & 37.1 & 9.9 & 12 & 1165.6 & 664.5 & 28 & 359.6 & 251.5 & 83 \\
\hline Strike \& non-rush hour & 47.6 & 3.9 & 94 & 864.6 & 426.8 & 270 & 146.6 & 128.6 & 727 \\
\hline Non-strike \& rush hour & 42.0 & 9.5 & 88 & $1,060.5$ & 615.7 & 256 & 241.9 & 188.8 & 664 \\
\hline Non-strike \& non-rush hour & 46.9 & 6.2 & 154 & 835.9 & 903.1 & 438 & 151.3 & 138.1 & 1,127 \\
\hline Rail strike & 45.9 & 4.7 & 56 & 875.4 & 404.1 & 363 & 138.0 & 89.1 & 517 \\
\hline Regional bus strike & 43.8 & 7.5 & 164 & $1,011.8$ & 510.6 & 465 & 229.2 & 847.1 & 1,256 \\
\hline Placebo strike & 46.3 & 5.4 & 98 & 760.9 & 468.6 & 363 & 122.3 & 121.7 & 1,201 \\
\hline Non-strike & 47.8 & 6.1 & 87,146 & 774.9 & 465.5 & 335,772 & 118.2 & 117.0 & 711,878 \\
\hline Rush hour & 44.6 & 7.9 & 17,828 & 988.2 & 557.3 & 68,545 & 197.2 & 150.6 & 145,525 \\
\hline Non-rush hour & 48.6 & 5.2 & 69,318 & 720.1 & 421.8 & 267,227 & 97.9 & 96.8 & 566,353 \\
\hline Total & 47.8 & 6.1 & 88,106 & 775.9 & 457.0 & 338,782 & 118.9 & 123.1 & 719,661 \\
\hline
\end{tabular}

Note: Hourly observations

Table 3a shows mean car speed for different strike categories. Note that when there are no strikes, speed during rush hours $(44.6 \mathrm{~km} / \mathrm{h})$ is only $10 \%$ lower than during non-rush hours $(48.6 \mathrm{~km} / \mathrm{h})$, in line with the idea that Rotterdam is an uncongested city. The table also shows the effect of strikes: car speed is distinguishably lower during full-day citywide strikes in comparison to non-strike hours. The difference in mean speed is about $3.3 \mathrm{~km} / \mathrm{h}$, so about $7 \%$. At the same time, mean car and bicycle flows are substantially larger during full-day citywide strikes in comparison to non-strike days. During rush hours of full-day citywide strikes, mean

\footnotetext{
${ }^{16}$ To be precise, intervals distinguish between 0-31, 31-41, 41-51, 51-57, 57-61, 61-71, 71-81, 81-91, 91-101, and above $101 \mathrm{~km} / \mathrm{h}$.

${ }^{17}$ For a number of cars, speed is unknown. We ignore these observations initially. In the sensitivity analyses, we re-estimate models with the proportion of cars with missing speed data as a control variable.
} 
car speed is much lower, about $17 \%$, compared to non-strike days. ${ }^{18}$ For most strike categories, the number of speed observations is high enough to anticipate reasonably precise estimates. For example, for full-day citywide strikes, we have 294 observations about car speed, 854 about car flow and 2,212 observations for bicycle flow.

\section{Full-Day Strike}

Figure 3a - Car speed Thursdays June 2011

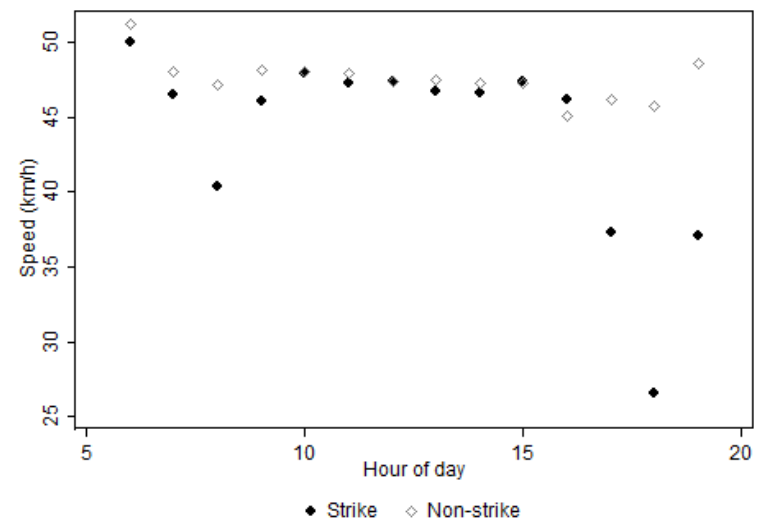

Figure 3b - Car flow Thursdays June 2011

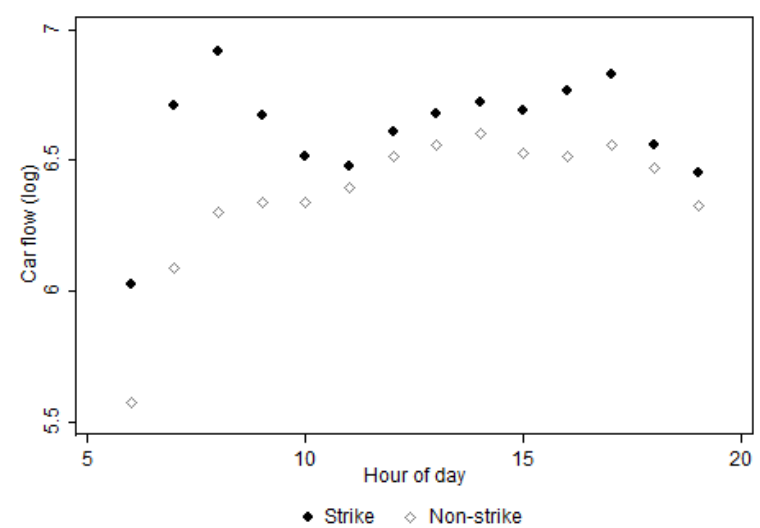

Partial-Day Strike

Figure 4a - Car speed Wednesdays May 2011

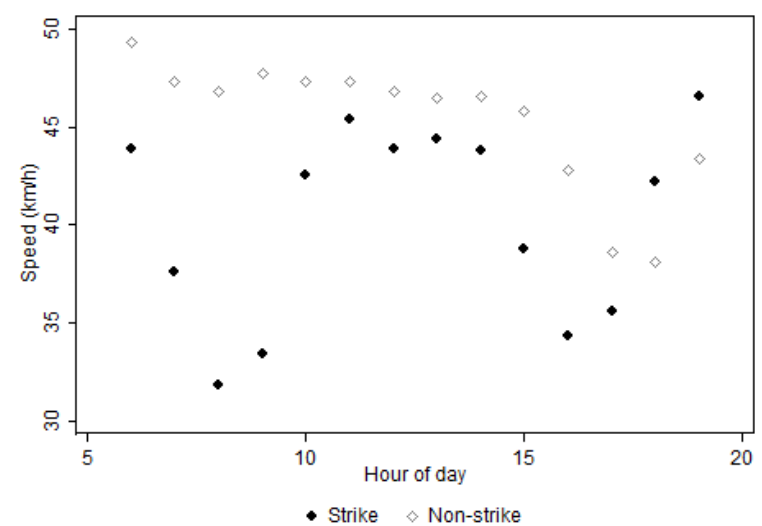

Figure 4b - Car flow Wednesdays May 2011

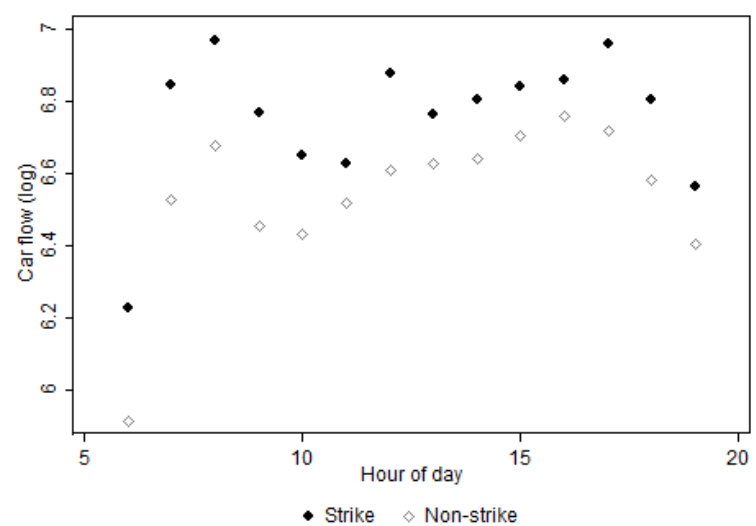

A visual examination of how transport outcomes vary over the day on days with and without strikes offers further insights which motivates our estimation methodology later on. Here, we compare transport outcomes on particular strike day to transport outcomes on nonstrike days on the same weekday of the same month of the strike.

Figures 3a and 3b show car speed and car flow for a strike on a Thursday, on the $9^{\text {th }}$ of June 2011 and for other (non-strike) Thursdays of the same month. During this particular

\footnotetext{
${ }^{18}$ For rail and placebo strikes, speeds and flow are similar to non-strike days, suggesting the absence of an effect. For strikes with lower speed and a larger flow, standard deviations of speed tend to be larger (because of the increase in speed variation over the day).
} 
strike, which lasted a full day, car flows are larger and car speed is lower for most hours of the day compared to other (non-strike) Thursdays that month. This result for car flow also hold for bicycle flow, see Figure A2 in the Appendix.

Figures 4a and 4b provide information for a partial-day strike - between 5am and 9am - on Wednesday $11^{\text {th }}$ of May 2011 and compare this to all other non-strike Wednesdays in that month. The outcomes of this partial strike appear similar to the full-day strike, suggesting that strikes effect speed also outside the strike period. Importantly, non-strike flow patterns between Thursdays and Wednesdays (see again Figures 3b and 4b) reveal weekday-specific flow patterns. For example, the morning rush hour is more pronounced on Wednesdays. It seems therefore important to control for the interaction of the week of the day and hour of the day fixed effects in the multivariate analysis.

\subsection{Highway Traffic}

We also make use of highway ring road data between 6am and 8pm for the year 2011 that are collected using induction loops (Snelder, 2010). Our data refer to the A16 motorway, east of Rotterdam. The maximum speed limit is $100 \mathrm{~km} / \mathrm{h}$ on this stretch of the road. We use 5 minute data on both directions (that have 3 lanes each) for 7.6 kilometers (between the intersections with the northern and southern part of the ring road, A17 and A20). Because of frequent malfunction of loop detectors, data has been transformed to 100 meter virtual loop data (Vukovic et al., 2013). ${ }^{19}$ We aggregate over time to create hourly observations of speed and flow.

We have 771,019 hourly observations, see Table 3b. Average highway flow is 2,963 cars per hour. Average speed is $96.8 \mathrm{~km} / \mathrm{h}$, close to the maximum speed limit, with a rather small standard deviation of 12.8 suggesting that congestion is not a major issue on this highway road. So, a priori, one does not expect particularly strong effects of a strike. This is confirmed by the data. During a full-day citywide strike, car speed is only $1.3 \mathrm{~km} / \mathrm{h}$ lower, about $1.3 \%$, than during non-strike hours. However, focusing on averages over the whole day is slightly misleading because during strike rush-hours, the effect of strikes is much more pronounced: for example, during citywide strikes, speeds are reduced by about $8 \%$ and highway flows increase by about $40 \%$.

\footnotetext{
${ }^{19}$ Induction loops are almost as frequent as virtual loop but have varying distances.
} 
Table 3b - Summary statistics highway traffic

\begin{tabular}{lcccccc}
\hline & \multicolumn{3}{c}{ Car speed } & \multicolumn{3}{c}{ Car flow } \\
& Mean & SD & Obs. & Mean & SD & Obs. \\
\hline Full-day citywide strike & 95.5 & 10.4 & 6,426 & 3,033 & $1,244.0$ & 6,426 \\
$\quad$ Rush hour & 86.6 & 15.5 & 1,224 & 4,340 & 886.4 & 1,224 \\
$\quad$ Non-rush hour & 97.6 & 7.4 & 5,202 & 2,753 & $1,113.1$ & 5,202 \\
Partial-day citywide strike & 93.0 & 13.8 & 5,202 & 3545 & 957.0 & 5,202 \\
$\quad$ Strike \& rush hour & 86.2 & 17.7 & 306 & 3,981 & 638.6 & 306 \\
$\quad$ Strike \& non-rush hour & 91.4 & 14.8 & 459 & 3169 & 481.9 & 459 \\
$\quad$ Non-strike \& rush hour & 83.9 & 19.3 & 1,377 & 4,160 & $1,123.5$ & 1,377 \\
$\quad$ Non-strike \& non-rush hour & 98.0 & 4.8 & 3,060 & 3,282 & 796.7 & 3,060 \\
Placebo strike & 100.6 & 11.9 & 1,836 & 2,288 & $1,089.2$ & 1,836 \\
Non-strike & 96.8 & 11.9 & 757,555 & 2,960 & $1,150.4$ & 757,555 \\
$\quad$ Rush hour & 92.6 & 16.3 & 208,903 & $3,354.3$ & $1,484.9$ & 208,903 \\
$\quad$ Non-rush hour & 98.3 & 9.3 & 548,652 & $2,809.4$ & 951.7 & 548,652 \\
\hline Total & 96.8 & 11.9 & 771,019 & 2,963 & $1,151.3$ & 771,019 \\
\hline
\end{tabular}

Again we show car flow for a full-strike and a partial-strike day and compare it to car flow on the same non-strike weekdays that month (Figures $5 b$ and $6 b$ ). Similar to inner city roads, highway flows are larger during strike hours, especially for the full-day strike. In Figures $5 \mathrm{a}$ and $6 \mathrm{a}$, it is shown that speed is lower during strike hours than during the same weekdays that month.

\section{Full-Day Strike}

Figure 5a - Car speed on Thursdays June 2011

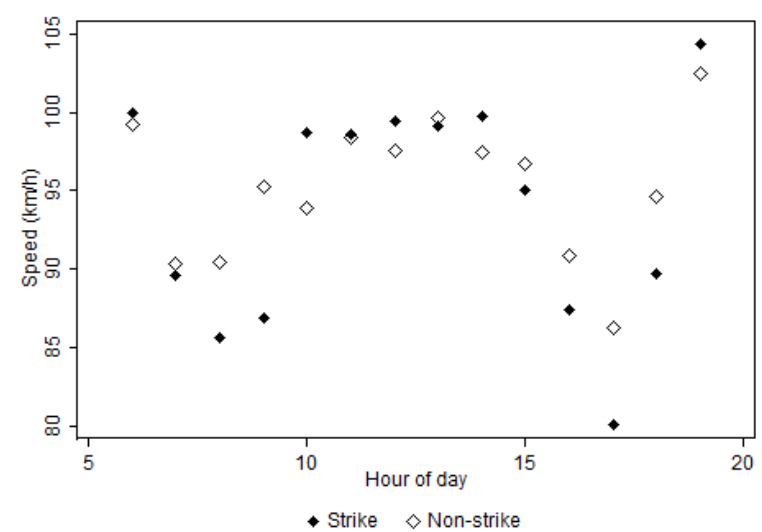

Figure 5b - Car flow on Thursdays June 2011

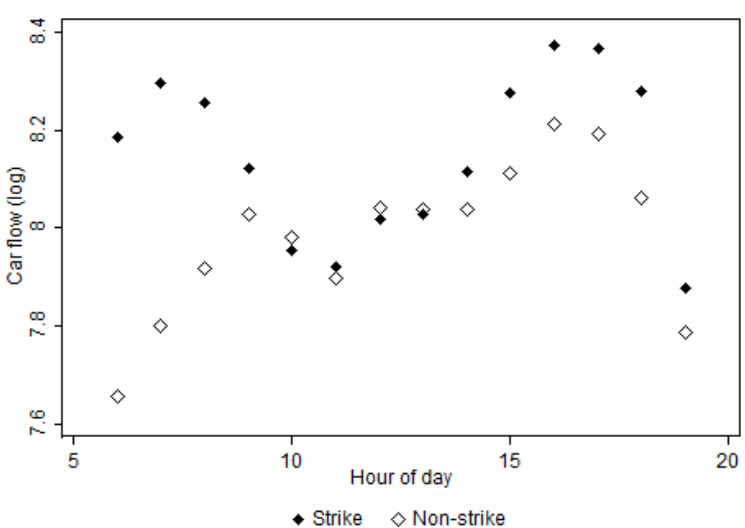


Figure 6a - Car speed on Wednesdays May 2011

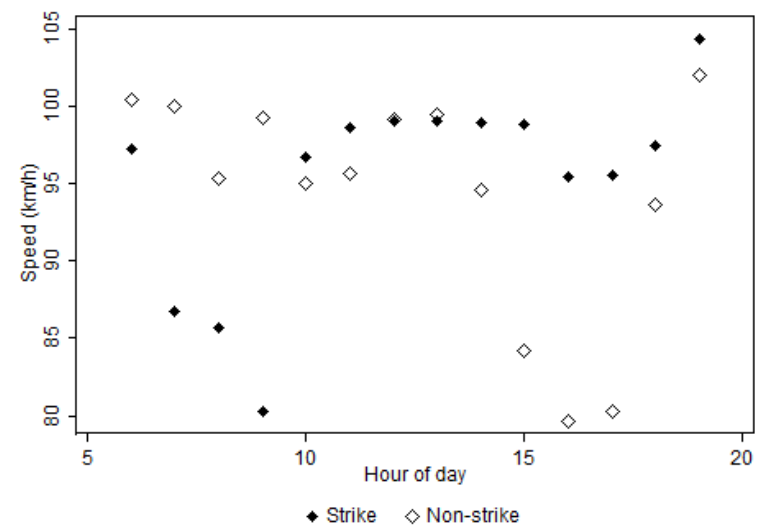

Figure 6b - Car flow on Wednesdays May 2011

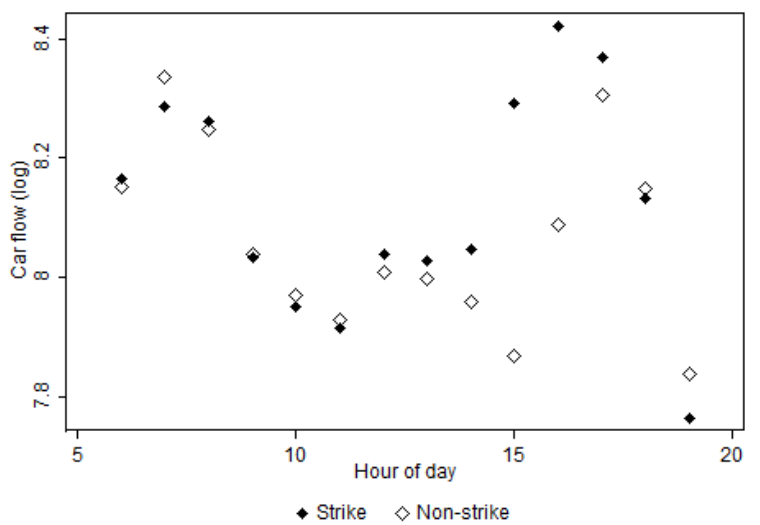

\section{Method}

To estimate the public transit strike effects, we use log-linear models. ${ }^{20}$ We focus on the effect of citywide strikes. For these strikes, we distinguish between the effect of a full-day strike, the effect of a partial-day strike during strike hours and the effect of a partial-day strike outside strike hours. Because in the previous sections we have seen that the effects of strikes seem to differ for rush and non-rush hours, we also distinguish between rush hours and nonrush hours effects.

To estimate these different strike effects, we assume that the dependent variable $\log Y_{i, t, D}$ (i.e. car speed, car flow or bicycles flow), which is observed for a certain direction $i$, of hour $t$ on day $D$, depends on a citywide full-day strike dummy $F_{D}$, a rush hour dummy $R_{t}$, a dummy variable $S_{t, D}$ for strikes at hour $t$ of day $D$, control variables $X_{t, D}$, direction fixed effects $a_{i}$, and a random error term $u_{i, t, D}$ in the following way:

$$
\begin{aligned}
\log Y_{i, t, D}=\alpha_{i}+ & \beta_{x} X_{t, D}+\left[\beta_{1} R_{t}+\beta_{2}\left(1-R_{t}\right)\right] F_{D} \\
& +\left[\left(\beta_{3} R_{t}+\beta_{4}\left(1-R_{t}\right)\right) S_{t, D}+\left(\beta_{5} R_{t}+\beta_{6}\left(1-R_{t}\right)\right)\left(1-S_{t, D}\right)\right] P_{D}+u_{i, t, D}
\end{aligned}
$$

In this way, the coefficient $\beta_{1}$ captures the citywide strike effect for a full-day strike during rush hours and $\beta_{2}$ captures the same effect but outside rush hours. For partial-day strikes during strike hours, $\beta_{3}$ captures the strike effect during rush hours and $\beta_{4}$ for non-rush hours. The effect during non-strike hours of partial-day strikes are captured by $\beta_{5}$ and $\beta_{6}$ for rush hours and non-rush hours, respectively.

\footnotetext{
${ }^{20}$ Our results are robust to specification. For example, for a linear specification of speed we got almost identical results.
} 
The control variables $X_{t, D}$ include the placebo strikes, the regional bus strike, the rail strike and weather condition variables (precipitation, temperature and wind speed). ${ }^{21}$ We also control for a range of time controls. We control for 'special' days (i.e. Christmas, Queens Day and the annual marathon), hour of the week (i.e., the interaction between hour of the day and day of the week) and week of the year (i.e., the interaction between week and year). ${ }^{22}$

The range of time controls are included because we have seen in the previous section that traffic flows follow certain time patterns during the day, but also to address the possibility that the strike date might be endogenous. For example, negotiating parties (i.e. unions, transport firms and the government) determine when strikes occur and might take the effect on car speed into account by not selecting certain days. So, occurrence of a strike is likely not fully random with respect to day of the week. This is also suggested by Table 1. For example, there are no citywide strikes on Fridays or Saturdays. Hence, including time controls is useful for consistency and efficiency reasons. Furthermore, to deal with heteroscedasticity and dayspecific unobservables, we choose standard errors that are robust and clustered by day.

\section{Empirical Results}

\subsection{Inner City Traffic}

We report strike effects on car speed, car flow and bicycle flow of estimating equation (1) in Table 4. First, we discuss the citywide strike effects. ${ }^{23}$ Our results in the first column indicate that a full-day citywide strike during rush hours decreases car speed by $15 \%$ (about $7 \mathrm{~km} / \mathrm{h}$ ), implying an additional 0.189 minutes per km traveled. ${ }^{24}$ We interpret this as a strong effect: for example, the effect is about 50\% higher than the one reported by Anderson (2014) for Los Angeles highways and several times higher than those assumed by Parry and Small (2009). Our result verifies the assumption by Anderson (2014) that car drivers on inner-city roads benefit substantially more from public transit through reduced car congestion than car drivers on highways.

This speed decrease is in line with a 9\% increase in car flow during rush hours, as reported in the second column. This result is in line with the literature which shows that the

\footnotetext{
${ }^{21}$ Daily travel demand, and bicycle travel in particular, depends strongly on weather, see, for example Thomas et al. (2013).

${ }^{22}$ Hour of the week contains a dummy for each combination of the hours of the day (14) and day of the week (7), in total 98. Week of the year has a dummy for each week (40) of the year (8), in total 320.

${ }^{23}$ See Table A2 in the Appendix for individual strike effects.Individual effects are more difficult to interpret given the presence of unobserved day-specific random error. By combining individual effects into categories, any small sample bias due to day-specific random error is substantially reduced.

${ }^{24}$ We calculate the additional time per kilometer by multiplying the percentage of speed reduction with the time it takes to travel $1 \mathrm{~km}$. Note that $0.151 * 3600 /(47.8 * 60)=0.189$, where 47.8 is the average speed. Also, note that we interpret coefficients as percentage changes.
} 
strike effect on car flow is usually in the range of 5\% to 30\% (Van Exel and Rietveld, 2001). Furthermore, a full-day citywide strike increases bicycle flow by $24 \%$ implying that a large share of travelers switch to bicycle use (rather than car use), which presumably reduces the car flow increase and therefore the speed reduction of a strike. Bicycle ownership and use is much higher in the Netherlands than in other countries in the world, so this result is likely specific to the Netherlands. The reduction in speed during non-rush hours is smaller and only $6 \%$. Hence, one immediate, but maybe obvious, implication is that the benefit of public transit provision in terms of congestion reduction is smaller outside rush hours. ${ }^{25}$

Table 4 - Car speed, car and bicycle flow (by strike)

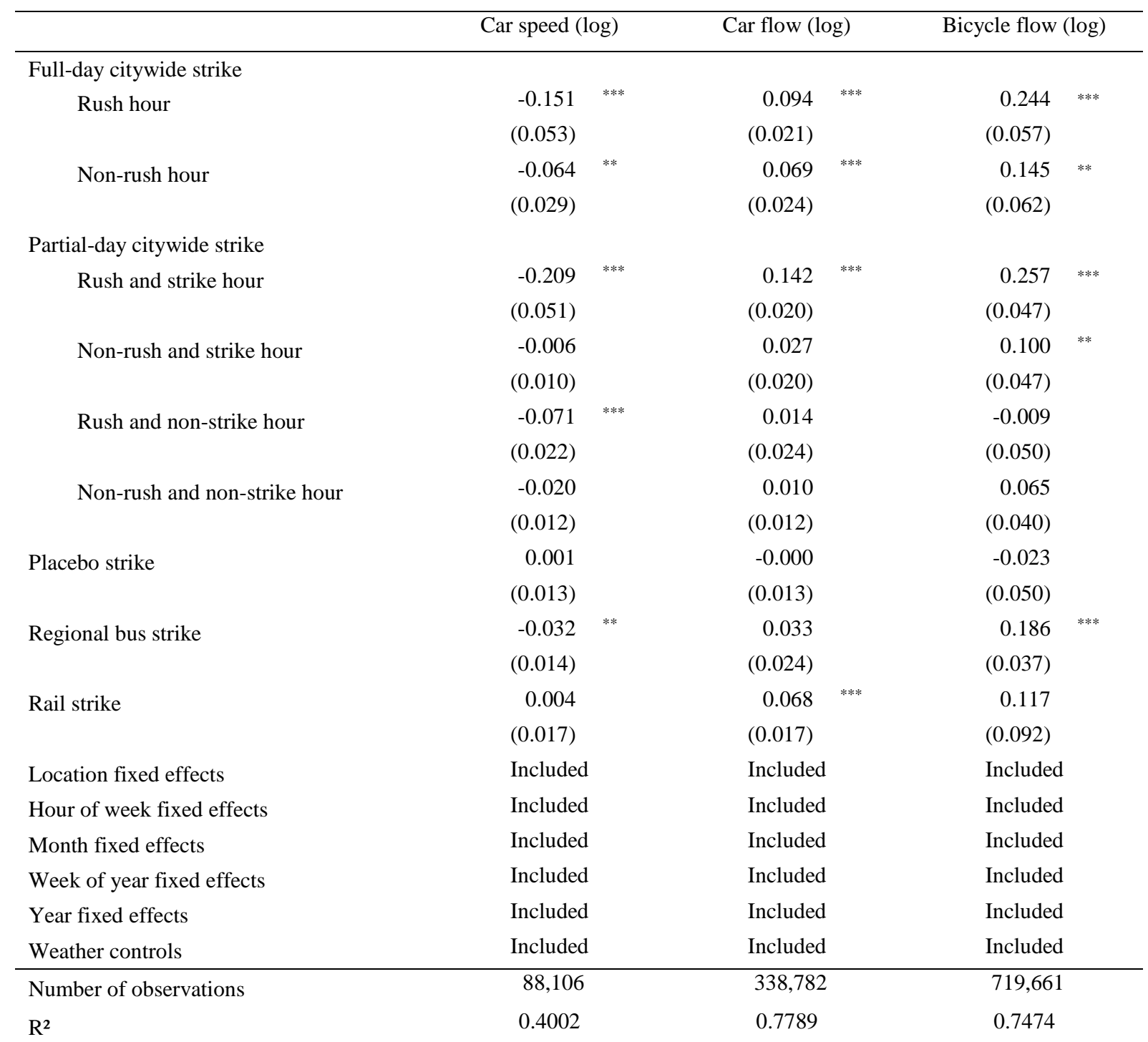

Note: ***, **, * indicate 1\%, 5\% and 10\% significance levels. Standard errors in parentheses are robust and clustered by day. The rail and placebo strike effects on car speed are based on one and two strikes, respectively.

\footnotetext{
${ }^{25}$ For non-rush hours, travel demand tends to be lower. Moreover, there is a lower share of commuters, so trip rescheduling and trip cancellation is likely less costly to travellers. However, increases in car flows are similar (the p-value 0.174 of a F-test is) for full-day strike rush and non-rush hours. The same holds for bicycle flows (pvalue 0.113$)$.
} 
Later on, for our welfare calculations, it is accurate to use a weighted average of the full-day citywide strike effect, because we are interested in the average effect of a strike for each car traveler, so we wish to take into account that rush hours are less frequent than nonrush hours, but we also like to take into account that during rush hours, there is a higher flow of cars. We weight the rush and non-rush hour coefficients with their share of hours over the day and their share of vehicle flow (see Table 3a). ${ }^{26}$ On average, full-day citywide strikes decrease speed by $10.3 \%$ and increase flow by $8.1 \%$, implying 0.129 minutes additional travel time per kilometer traveled.

For partial-day strikes, outside strike hours, but during rush hours, strikes decrease speed by a similar percentage (7\%). ${ }^{27}$ In addition, our results suggest that the speed effects of strikes that last a few hours are similar to full-day strikes strongly suggesting that a continuous supply of public transit during the full day is essential for travelers. We have also estimated models where we allow for strike effects on days before and after the strike. We find no changes in car flow or speed that extend to days before and after the strike. Interestingly, we find a (very) small effect on bicycle flow for the working day after a strike but no effect two working days after the strike. Apparently travelers hardly change their travel behavior 'permanently' due to a strike. ${ }^{28}$

We find no effect on speed by the three placebo strikes. This gives us more confidence in the methodology used. As argued above, placebo strikes are defined by us as (announced) strikes which are canceled, so given a large effect of announcement, canceled strikes may not be interpreted as placebo strikes. ${ }^{29}$ For this reason, we have tested the effect of announcement by including an announcement dummy. We do not find an effect of announcement on speed, suggesting that canceled strikes can be interpreted as placebo strikes.

\footnotetext{
${ }^{26}$ The share of rush hours of the number of hours included in our analysis is 0.29 . The share of car flow during rush hours is 0.57 (see Table 3a). Note that $0.103 * 3600 /(47.8 * 60)=0.129$.

${ }^{27}$ For partial-day strikes, the point estimate of a strike during rush hours and strike hours is $21 \%$, but despite the larger coefficient, the effect is not statistically different (p-value 0.426); likely due to the limited number of observations which is only 12 .

28 The regional bus strike particularly increases bicycle flow (by 19\%). This is a relatively large increase, considering that the strike took place in non-rush hours and a low modal share of regional buses. An explanation for this relatively large effect is that the strike overlapped with national school exams, so many students switch to bicycle use. We find no effect on inner city car speed for national rail strikes. We also find no effect on bicycle flow. The latter is not so surprising because bicycle and rail are complements in the Netherlands as about half of travelers use the bicycle as an access or egress mode for rail. One explanation for these findings is that the share of rail in passenger transport is low in Rotterdam (2.7\%), see De Vries (2013). Moreover, there are only two rail strikes, so these estimates are less reliable.

${ }^{29}$ Strike announcement has likely an effect on travel behavior according to Van Exel and Rietveld (2001).
} 


\subsection{Sensitivity analyses for car speed on inner city roads}

To verify the robustness of our results for car speed we conduct a range of sensitivity analyses. We find our results to be robust to various speed specifications. Table 5 shows the main results. For example, it is well known that the pneumatic tube speed measurement techniques perform less well at lower speeds. Consistent with that, we observed that there is a higher proportion of missing observations at lower speeds. Hence, in the first column, we include the proportion of cars with unknown speed as a control variable. We find that strike effects are somewhat reduced, but not extremely. ${ }^{30}$ Note that this control variable is highly endogenous and likely biases the strike effect towards zero, so we interpret the latter specification as an extreme underestimate and prefer the estimates of Table 4 without this additional control variable.

In the calculation of speed, we have assumed that cars in the lowest speed interval less than $31 \mathrm{~km} / \mathrm{h}$ - travel at an average speed of $15 \mathrm{~km} / \mathrm{h}$. To see how much our results depend on this assumption, we estimate a model where all cars in the lowest speed interval are assumed to travel at $31 \mathrm{~km} / \mathrm{h}$. Now we find that during full-day citywide strike rush hours, speed declines by $7 \%$ (see column 2). Note that we interpret this estimate as the minimum effect because this approach strongly biases our results towards zero. To prove this latter point, we estimate a model where the dependent variable is the share of speed observations above $31 \mathrm{~km} / \mathrm{h}$ (see column 3). Reassuringly, the signs of the strike effects are in line with the main results: for example, given a full day citywide strike, the share of speed observations that exceed $31 \mathrm{~km} / \mathrm{h}$ drops by 0.118 during rush hours.

Four of the 13 citywide strikes are not complete, in the sense that some public transit is still supplied for the metro or that only the time schedule has been reduced (see Table 1). Consequently, it is plausible that our estimates are underestimates of complete strikes which are more representative to capture the congestion relief benefit of public transit. We therefore re-estimate the model excluding these four incomplete strikes. The rush hour, full-day citywide strike effect becomes more pronounced and is now equal to -0.201 . This result is in line with the idea that complete strikes entail larger speed reductions. Hence, importantly, it is plausible that using the estimates of Table 4 will lead to underestimates of the congestion relief benefit.

\footnotetext{
${ }^{30}$ In addition, as expected, we find a negative relationship between the number of cars with unknown speed and average speed.
} 
Table 5 - Car speed, car and bicycle flow (by strike)

\begin{tabular}{|c|c|c|c|c|c|c|c|c|c|c|}
\hline & \multicolumn{2}{|c|}{ Car speed (log) } & \multicolumn{2}{|c|}{ Car speed (log) } & \multicolumn{2}{|c|}{ Speed share } & \multicolumn{2}{|c|}{ Car speed (log) } & \multicolumn{2}{|c|}{ Car speed (log) } \\
\hline \multicolumn{11}{|l|}{ Full-day citywide strike } \\
\hline \multirow{2}{*}{ Rush hour } & -0.115 & *** & -0.073 & *** & -0.118 & *** & -0.201 & *** & -0.230 & *** \\
\hline & $(0.039)$ & & $(0.023)$ & & $(0.044)$ & & $(0.045)$ & & $(0.060)$ & \\
\hline \multirow[t]{2}{*}{ Non-rush hour } & -0.045 & $* *$ & -0.032 & $* *$ & -0.049 & ** & -0.081 & ** & -0.053 & \\
\hline & $(0.019)$ & & $(0.014)$ & & $(0.024)$ & & $(0.034)$ & & $(0.039)$ & \\
\hline \multicolumn{11}{|l|}{ Partial-day citywide strike } \\
\hline \multirow[t]{2}{*}{ Rush and strike hour } & -0.190 & $* * *$ & -0.103 & $* * *$ & -0.172 & **** & -0.103 & *** & -0.286 & *** \\
\hline & $(0.047)$ & & $(0.017)$ & & $(0.049)$ & & $(0.015)$ & & $(0.074)$ & \\
\hline \multirow{2}{*}{$\begin{array}{l}\text { Non-rush and strike } \\
\text { hour }\end{array}$} & -0.001 & & -0.006 & & -0.001 & & -0.009 & & -0.003 & \\
\hline & $(0.009)$ & & $(0.005)$ & & $(0.007)$ & & $(0.008)$ & & $(0.020)$ & \\
\hline \multirow{2}{*}{$\begin{array}{l}\text { Rush and non-strike } \\
\text { hour }\end{array}$} & -0.057 & *** & -0.034 & $* * *$ & -0.050 & ** & -0.058 & ** & -0.156 & *** \\
\hline & $(0.014)$ & & $(0.008)$ & & $(0.020)$ & & $(0.025)$ & & $(0.040)$ & \\
\hline \multirow{2}{*}{$\begin{array}{l}\text { Non-rush and non-strike } \\
\text { hour }\end{array}$} & -0.020 & * & -0.013 & * & -0.014 & & -0.027 & & -0.031 & \\
\hline & $(0.011)$ & & $(0.007)$ & & $(0.010)$ & & $(0.018)$ & & $(0.028)$ & \\
\hline \multirow[t]{2}{*}{ Placebo strike } & 0.001 & & -0.004 & & 0.005 & & 0.001 & & 0.030 & \\
\hline & $(0.008)$ & & $(0.005)$ & & $(0.014)$ & & $(0.013)$ & & $(0.037)$ & \\
\hline \multirow[t]{2}{*}{ Regional bus strike } & -0.024 & $* * *$ & -0.010 & * & -0.038 & $* * *$ & -0.032 & ** & -0.097 & *** \\
\hline & $(0.008)$ & & $(0.006)$ & & $(0.013)$ & & $(0.014)$ & & $(0.010)$ & \\
\hline \multirow[t]{2}{*}{ Rail strike } & -0.007 & & -0.006 & & 0.012 & & 0.017 & & 0.023 & \\
\hline & $(0.012)$ & & $(0.010)$ & & $(0.014)$ & & $(0.016)$ & & $(0.046)$ & \\
\hline \multirow[t]{2}{*}{ Proportion unknown speed } & -2.412 & *** & & & & & & & & \\
\hline & $(0.139)$ & & & & & & & & & \\
\hline Time/weather controls & \multicolumn{2}{|c|}{ Included } & \multicolumn{2}{|c|}{ Included } & \multicolumn{2}{|c|}{ Included } & \multicolumn{2}{|l|}{ Included } & \multicolumn{2}{|c|}{ Not included } \\
\hline \multirow{2}{*}{$\begin{array}{l}\text { Number of observations } \\
\mathrm{R}^{2}\end{array}$} & \multicolumn{2}{|l|}{88,106} & \multicolumn{2}{|c|}{88,106} & \multicolumn{2}{|c|}{88,106} & \multicolumn{2}{|l|}{87,882} & \multicolumn{2}{|c|}{88,106} \\
\hline & \multicolumn{2}{|l|}{0.5898} & \multicolumn{2}{|c|}{0.6500} & \multicolumn{2}{|l|}{0.1871} & 0.4007 & & 0.0041 & \\
\hline
\end{tabular}

Note: In the second column, cars below $31 \mathrm{~km} / \mathrm{h}$ censored at 31 . Third column, the dependent variable is the share of cars at speeds exceeding $31 \mathrm{~km} / \mathrm{h}$. Fourth column, we exclude the four citywide strikes that were not a complete public transit cancellation. Last column, we do not include controls. See Table 4 for control variables. ***, **, * indicate $1 \%, 5 \%$ and $10 \%$ significance levels. Standard errors in parentheses are robust and clustered by day.

In the fifth column of Table 5, we re-estimate the model without any time or weather condition control variable. Not surprisingly, standard errors tend to increase due to a less efficient estimation specification. The effects are identical in sign to those in Table 4 and usually of a similar magnitude, which gives confidence in our results in the sense that overall results do not strongly depend on these control variables.

\subsection{Highway Traffic}

We now focus on the strike effects on the highway ring road. It appears that citywide strikes also have a negative effect on highway speed, see Table 6. However, in comparison to inner city roads, speed reductions are much smaller. In particular, even during rush hours, the effect 
is only about $3.7 \%(4 \mathrm{~km} / \mathrm{h})$ during full-day citywide strikes. This decrease corresponds to an increase of 0.023 minutes travel time per km traveled. ${ }^{31}$

Table 6- Car speed and flow on highways

\begin{tabular}{|c|c|c|c|c|}
\hline & Car speed (lo & & Car flow (lo & \\
\hline \multicolumn{5}{|l|}{ Full-day citywide strike } \\
\hline \multirow[t]{2}{*}{ Rush hour } & -0.037 & $* * *$ & 0.031 & * \\
\hline & $(0.010)$ & & $(0.017)$ & \\
\hline \multirow[t]{2}{*}{ Non-rush hour } & -0.025 & $* * *$ & -0.017 & \\
\hline & $(0.010)$ & & $(0.028)$ & \\
\hline \multicolumn{5}{|l|}{ Partial-day citywide strike } \\
\hline \multirow[t]{2}{*}{ Rush and strike hour } & -0.068 & $* * *$ & -0.040 & * \\
\hline & $(0.018)$ & & $(0.023)$ & \\
\hline \multirow[t]{2}{*}{ Non-rush and strike hour } & -0.071 & $* * *$ & -0.044 & $* *$ \\
\hline & $(0.013)$ & & $(0.021)$ & \\
\hline \multirow[t]{2}{*}{ Rush and non-strike hour } & -0.035 & & -0.073 & *** \\
\hline & $(0.058)$ & & $(0.024)$ & \\
\hline \multirow[t]{2}{*}{ Non-rush and non-strike hour } & 0.021 & $*$ & -0.016 & \\
\hline & $(0.011)$ & & $(0.025)$ & \\
\hline \multirow[t]{2}{*}{ Placebo strike } & -0.015 & & 0.002 & \\
\hline & $(0.010)$ & & $(0.021)$ & \\
\hline \multirow[t]{2}{*}{ Number of observations } & 771,019 & & 771,019 & \\
\hline & 0.2152 & & 0.8175 & \\
\hline
\end{tabular}

Note: See Table 4 for control variables. ***,**, * indicate $1 \%, 5 \%$ and $10 \%$ significance levels. Standard errors in parentheses are robust and clustered by day.

The (weighted) average speed decline of a full-day citywide strike is even slightly lower and equal to 3\%, 0.019 minutes travel per km traveled. ${ }^{32}$ We will use this result in our welfare calculations later. We interpret this result as a small effect: it is several times smaller than reported by Anderson (2014) for Los Angeles (and about half of the assumption made by Parry and Small, 2009). We can only speculate about explanations for this difference in the magnitude of the effect. The main explanation is likely that the highways in Los Angeles that are chosen by Anderson (2014) are more congested than those of Rotterdam.

Despite the presence of a strike effect on speed, we find little or no increase in flow on highways. Importantly, this finding is similar to Lo and Hall (2006) and Anderson (2014). One explanation is purely statistical, in the sense that the standard errors are too large to estimate the effect at conventional significance levels. An alternative explanation, which is equally plausible, is that congestion on highways induces queuing at bottlenecks which

\footnotetext{
${ }^{31}$ Note that $0.037 * 3600 /(96.8 * 60)=0.023$. Reassuringly, we find no impact of a placebo strike effect.

${ }^{32}$ For rush hours, the share of hours over the day is 0.28 and the share of flow is 0.61 . Note that $0.030 *$ $3600 /(96.8 * 60)=0.019$.
} 
prevent cars from entering the highway, so flows into the highway decline. The latter happens much less within inner cities and then only in case of extreme congestion (as observed for Asian cities by Geroliminis and Dagazo, 2008). ${ }^{33}$ In Rotterdam, this does not occur: within the inner city, there are very few observations with low car speed and flow (which are likely due to roadworks, accidents etc).

\subsection{Traffic accidents}

So far, we have focused on car speed as affected by public transit strikes. However, it is possible that public transit provision effects traffic accidents, because public transit influence the travel mode of travelers as well as the speed on the road which both influence the frequency of accidents (Aljanahi et al., 1999). A priori, the effect of public transit strikes is ambiguous. The numbers of accidents is thought to increase with an increase in bicycle and traffic, whereas the number of severe incidents falls with car speed. So, it seems possible that during strikes the number of accidents increases whereas accident severity decreases.

We have (police-reported) daily traffic accidents data for Rotterdam for the years 2000 to 2009 (except for 2008). As is common in the literature using accident data, minor accidents are often not reported to the police, and so the data set comprises a larger share of severe accidents. The descriptives suggest that there might be a negative effect of strikes on the number of accidents: the average number of traffic accidents on strike days is substantially less than on other days (7.0 compared to 9.2). This result is consistent with the idea that public transit supply reduces accidents. However, when we estimate the effect of strike on number of accidents with similar controls as above, the results do not show any strike effect on accidents.

\section{Public transit congestion relief benefit}

We determine the welfare loss due to additional time losses by car travelers given a full-day citywide strike on a weekday. Arguably, this loss is equivalent to the public transit congestion relief benefit. We will assume a hourly value of time of $€ 14$ per person implying a hourly value of time of $€ 20$ per car. ${ }^{34}$

\footnotetext{
${ }^{33}$ For support of this claim, see Figures A4 and A5 in the Appendix where both for the highway as well as the inner city, the relationship between flow and speed is shown, commonly known as the fundamental diagram of traffic flow, see Small and Verhoef, 2007, p.84-88.

${ }^{34}$ In Rotterdam, a car contains on average 1.5 persons (CBS, 2014). We assume that the same occupancy rate applies during strikes. The assumed value of time is slightly higher than the commonly used value of time for commuters based on stated preference studies for the Netherlands, which is 10 euro. Our assumption can be justified because stated preference studies likely underestimate the true value and because a substantial proportion of car drivers travels for business for which the value of time likely exceeds €30 per hour. Assuming
} 
Table 8 - Number of trips per day for Rotterdam metropolitan area

\begin{tabular}{lccc}
\hline & Non-strike day & Strike day (\% change) & Differences \\
\hline Public transit & 348,000 & $-100 \%$ & $-348,000$ \\
Car (driver) & 804,000 & $+7.5 \%$ & 60,300 \\
Car (passenger) & 408.000 & $+7.5 \%$ & 32,600 \\
Bicycle & 588,000 & $+17 \%$ & 99,960 \\
Trips not replaced by car or bicycle & & & 155,140 \\
\hline
\end{tabular}

Note: Inner city train travel that that does not include another local form of local transport is negligible.

In Rotterdam, 1.2 million inhabitants conduct each day 348,000 public transit trips, 804,000 car driver trips, 408,000 car passenger trips, 588,000 bicycle trips and 765,000 walking trips, so in total 2.913 million trips (De Vries, 2013), see Table 8. During a full-day citywide strike, public transit is not available, so there are no public transit trips. Our estimates indicate that a strike induces car flow to increase by $7.5 \%$, so 60,300 additional car driver trips and 32,600 additional car passenger trips, and bicycle flow to increase by $17 \%$, so 99,960 trips. This implies that the increase in bicycle use is about equal to the increase in persons which travel by car. Furthermore, it means that 192,860 out of 348,000 canceled public transit trips are substituted by a car or bicycle trip. The other 155,140 trips are either rescheduled to another day, made by another mode not observed by us, most likely walking, or fully canceled. ${ }^{35}$

In Table 9, the annual congestion relief benefit is calculated for a range of assumptions. In Rotterdam, cars trips have an average length of $15 \mathrm{~km}$ of which $62 \%$ are driven on inner city roads and the remaining $38 \%$ on highways, see column 1 of Table $9 .{ }^{36}$ Given the estimated speed decrease of $10 \%$ on inner city roads (weighted averaged over hours and flows) and 3\% on highways, a strike induces an additional external cost of congestion of $€ 376,835$. The majority of this cost, €345,633, is on inner city roads, and additional $€ 31,201$ on highways. ${ }^{37}$ The annual public transit congestion relief benefit is then about €95 million

different value of time values for rush hours and nonrush hours might be more reasonable, but it appears that our results are not so sensitive to that. For example, we assume that the value of time is $€ 25$ per car during rush hours and $€ 15$ per car during non-rush hours then we obtain almost identical benefits.

${ }^{35}$ These results are in line with previous studies which report that during strikes $20 \%$ of canceled public transit trips are substituted by walking, 10\% fully canceled and 10\% rescheduled (PbIVV, 1984; van Exel and Rietveld, 2001). One of the main arguments against public transit subsidies is a low price cross elasticity between public transit and car use. Note that we do not examine changes in prices. However, we find that a quarter of the public transit users substitutes to car use during strikes.

${ }^{36}$ The share of car travel distances on inner city roads and highways are about the same in the Netherlands (CBS, 2014). For cities such as Rotterdam, one expects a higher share of inner city road use. On the highway ring road around Rotterdam we observe 331,744 trips per day, suggesting that $62 \%$ of trips are on inner city roads.

${ }^{37}$ The inner city road congestion relief benefit given a trip length of $15 \mathrm{~km}, 864,300$ car trips and a $€ 20$ per hour value of time is equal to $0.129 * 15 * 864,300 * 0.62 * 20 / 60=€ 452,807$. The highway congestion relief benefit is then equal to $0.022 * 15 * 864,300 * 0.38 * 20 / 60=€ 31,201$. 
(assuming 252 working days), so about $€ 79$ per inhabitant. This excludes any benefits of public transit provision on weekends that we assume to be negligible, so this is likely an underestimate. Given 721 million public transit passenger kilometers (OVPRO, 2014), the congestion reduction benefit per public transit kilometer is $€ 0.13$. This benefit is substantial given that the cost per public transit kilometer is $€ 0.46$. In addition to congestion welfare losses there are rescheduling costs to car travelers. ${ }^{38}$ We do not include these costs, nor do we include the loss to public transit ticket holders or any other external cost of car driving that are likely an order of magnitude smaller than the effect through congestion. ${ }^{39}$

Table 9 - Congestion relief benefit

\begin{tabular}{lccc}
\hline & $(1)$ & $(2)$ & (3) \\
\hline Area affected & Metropolitan & City & Metropolitan \\
Number of inhabitants affected & 1.2 million & 0.6 million & 1.2 million \\
Car trips weekday & 804,000 & 402,000 & 804,000 \\
Average trip distance & $15 \mathrm{~km}$ & $10 \mathrm{~km}$ & $15 \mathrm{~km}$ \\
Value of time per car & $€ 20$ per hour & $€ 20$ per hour & $€ 20$ per hour \\
Speed benefit inner city & 0.129 minutes per km & 0.129 minutes per km & 0.169 minutes per km \\
Speed benefit highway & 0.019 minutes per km & 0.019 minutes per km & 0.019 minutes per km \\
Inner city to highway km ratio & $62 / 38$ & $50 / 50$ & $62 / 38$ \\
Daily public transit benefit inner city & $€ 345,633$ & $€ 139,368$ & $€ 452,807$ \\
Daily public transit benefit highway & $€ 31,201$ & $€ 23,768$ & $€ 31,201$ \\
Overall public transit benefit & $€ 376,835$ & $€ 163,136$ & $€ 484,008$ \\
Annual public transit benefit & $€ 95$ million & $€ 41$ million & $€ 122$ million \\
(weekdays) & $€ 200$ million & $€ 200$ million & $€ 200$ million \\
Public transit subsidies & $47 \%$ & $21 \%$ & $61 \%$ \\
Congestion relief benefit to subsidies & $47 \%$ &
\end{tabular}

The costs of providing public transit in Rotterdam are partially covered by subsidies, about $€ 0.28$ per public transit kilometer. ${ }^{40}$ So, the congestion relief benefit is about $47 \%$ of subsidies. ${ }^{41}$ It is useful to examine this result under different assumptions. For example, if we

\footnotetext{
${ }^{38}$ We find that the peak hours start earlier and end later for citywide strikes, suggesting that these costs are not zero.

${ }^{39}$ Assuming, that the external cost of Co2 is $€ 100$ per km, the external benefit is only $€ 0.002$ per public transit $\mathrm{km}$.

${ }^{40}$ Annual subsidies for public transit were $€ 200$ million (Stadsregio Rotterdam, 2012). That is about $€ 166$ per capita, and about $0.3 \%$ of average gross salary. By comparison, bicycle infrastructure expenditure by the municipality is only €30 million per year (Savelberg, 2013). Note that bicycle lanes tend to reduce the width of roads, so the social cost of bicycle infrastructure will be higher than the expenditure by the municipality.

${ }^{41}$ Total operational cost of public transit was about $€ 333$ million. The farebox recovery for Rotterdam was between $35 \%-40 \%$ of operational cost, similar to many other cities with extensive public transit in Europe and the United States.
} 
assume that the specification of complete strikes is more indicative of the congestion relief benefit (Table 5, column 4), then this benefit is at least 61\% of subsidies (see column 3). In contrast, if we take the most conservative assumptions by assuming a trip length of $10 \mathrm{~km}$, an equal split in distance traveled on highway and inner city roads, and that only inhabitants in the city of Rotterdam (and not the whole metropolitan area) are affected by the strike, then the congestion relief benefit is only $21 \%$ of the subsidy (column 2). Hence, the congestion relief benefit is likely between $21 \%$ to $61 \%$ of the subsidy level.

This suggests that the congestion relief benefit alone is substantial but insufficient to justify the current supply of public transit in Rotterdam. Additional gains of public transit provision, such as economies of scale in public transit provision, since marginal cost of public transit is less than average cost, and productivity increases (Graham, 2007) might support current levels of subsidies. ${ }^{42}$ To do an overall welfare analysis of public transit provision for Rotterdam is beyond the scope of this paper.

It is important to emphasize that there are some reasons to believe that we have overestimated the congestion relief benefit but there are also reasons to believe that we have underestimated the congestion relief benefit of public transit. First, we have estimated the average, rather than the marginal, congestion relief benefit of public transit (by examining the effect of a public transit reduction towards zero). The marginal public transit benefit is likely decreasing in the public transit provision level (as congestion is likely a convex function of number of cars, see Small and Verhoef, 2007) and therefore smaller than the average benefit estimated by us. For policy recommendations, we are mostly interested in marginal changes in public transit supply, so, from this point of view, our estimates can be interpreted as underestimates. However, because congestion levels are rather low within Rotterdam, and because congestion within cities is almost linearly related to car flow for cities with low congestion (Geroliminis and Dagazo, 2008), it is plausible that this issue is not quantitatively important.

Second, strikes can be interpreted as crude approximation of counter-factual long-term adjustments in public transit supply as impact-related decisions regarding car ownership, work and residence location are ignored. ${ }^{43}$ It is extremely plausible that we underestimate the long-term congestion relief benefit by analysing the effect of strikes of short duration. First,

\footnotetext{
${ }^{42}$ Further, there are egalitarian reasons for subsidies, since public transit disproportionately supports the economically less well-off parts of society (see, e.g., Johnson, 2014, Compton and Pollack, 2014).

${ }^{43}$ As it is well known, household and firm location decisions depend on travel times, see, for recent contributions, Kok et al., 2014 and Johnson, 2014. Most papers reviewed by Van Exel and Rietveld (2001) do not suggest permanent losses in transport passengers for the mode under strike, because strikes are temporary. The estimated loss of public transit passengers after a strike is usually between $0.3 \%$ and $2.6 \%$.
} 
for these trips, it is likely that about 20\% are canceled or rescheduled (see also PbIVV, 1984; van Exel and Rietveld, 2001). For longer periods without public transit, particularly for commuting, it is unlikely that these trips are canceled or rescheduled. Second, in cities with good public transit, it is plausible to assume that car ownership is substantially lower than in other cities. For longer periods without public transit, current public transit travelers are likely to increase car ownership and use, so increasing car congestion. In Dutch rural areas, where public transit is virtually absent, car ownership per household is 30\% higher than in urban areas (CBS, 2014). Note that car ownership in rural areas is also lower because of lower densities so a $30 \%$ increase is likely a substantial overestimate of the increase in car ownership due to the absence of public transit.

One may also overestimate the public transit congestion relief benefit by focusing on short duration strikes, because residential and workplace location decisions are both affected by travel times to work and access to certain modes of transportation (Kantor et al., 2014). Without public transit, some households and firms would re-evaluate their location decision and may move closer to each other. However, this effect of location adjustments is likely smaller than the increase in congestion due to increase in car ownership. ${ }^{44}$

\section{Conclusion}

Public transit provision is a widely-accepted policy measure to reduce road congestion. The level of public transit provision and therefore the level of subsidies to public transit are usually subject of debate in many countries (e.g., Parry and Small, 2009; Anderson, 2014). We add to this debate by estimating the effect of multiple public transit strikes on car travel time losses for inner city roads and highways of Rotterdam, which is a rather uncongested city. This quasi-natural experiment allows us to determine the congestion relief benefit, i.e. the monetary value of a reduction in car congestion due to public transit provision.

We demonstrate that during a citywide strike, car speed within the city decreases by about $10 \%$. For highways, strikes exhibit a much smaller speed reduction of about 3\%. During rush hours, the reduction in speed is more pronounced. These results imply that during rush hours, public transit provision reduces car travel time on inner city roads by about 0.2 minutes

\footnotetext{
${ }^{44}$ One of the drivers of strikes is the joint cost to firms and employees that bargain about labour conditions such as wages, see Franzosi (1989) and Card (1990). Information about these cost is crucial to the negotiating parties' concession curves and hence bargaining. In case of public transit, outsiders of this bargaining process include car drivers when governments have no influence on the outcome of the bargaining process. When the transit firm is controlled by the government that is aiming to maximise welfare then it may be efficient that the government induces public transit firms to accept terms which would have been rejected from a private firm's consideration alone, although this may result in higher wages (Proost, 2014).
} 
per kilometer travelled, whereas it reduces car travel time on highways by 0.02 minutes per kilometer. Hence, for cities such as Rotterdam, travelers on inner city roads benefit much more from public transit provision than highway travelers. Our main finding is that for Rotterdam, the congestion relief benefit is substantial and equal to about one third of the public transit operating cost and half of subsidies to public transit. Consequently, this indicates that even for cities that are mildly congested, substantial subsidies to public transit are economically justified.

We also show that on a strike day, the increase in number of persons who travel by bicycle is about equal to the increase in the number of persons who travel by car. Although this may seem a typical result for a city in a country that is well known to have above-average bicycle use, we emphasise that bicycle use in Rotterdam is low from a Dutch perspective. This finding supports the claim that bicycle-promoting policies (such as bicycle lanes) may be a cost-effective way of reducing car travel time losses. 


\section{Appendix}

Figure A1 - Measurement stations bicycle

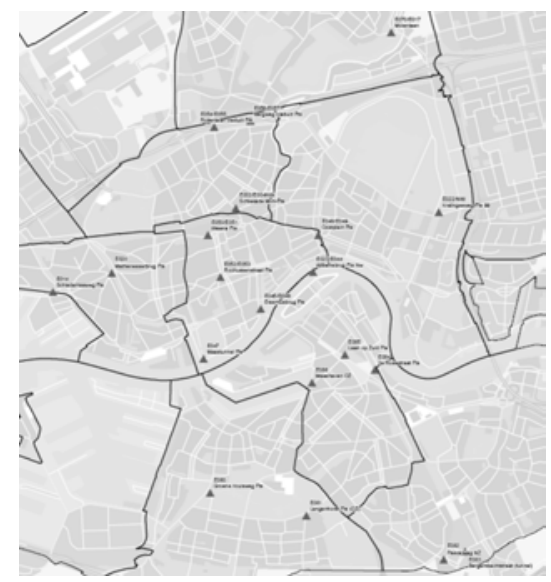

Source: Rotterdam municipality.

Table A1 - Number of measurement locations and directions

\begin{tabular}{lcc}
\hline Transport mode & Locations & Directions \\
\hline Car flow & 8 & 12 \\
Car flow and speed & 2 & 4 \\
Bicycle flow & 20 & 36 \\
\hline
\end{tabular}

Figure A2 - Bicycle flow Thursdays June 2011

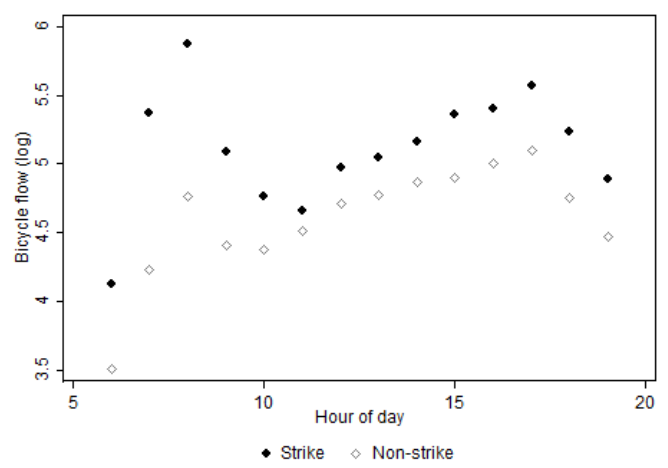

Figure A4 - Speed-flow relationship inner city roads

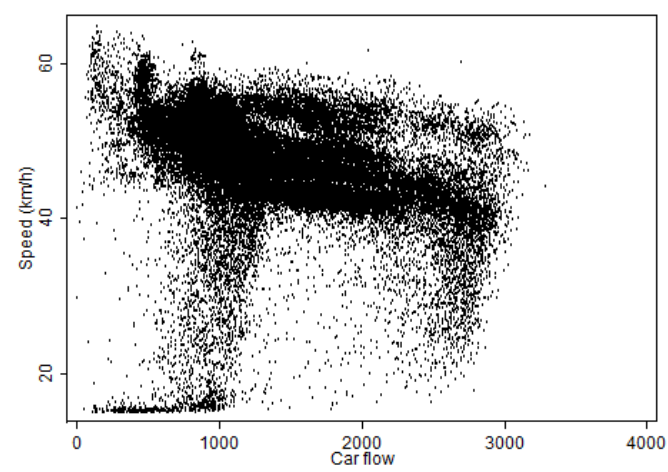

Figure A3 - Bicycle flow Wednesdays May 2011

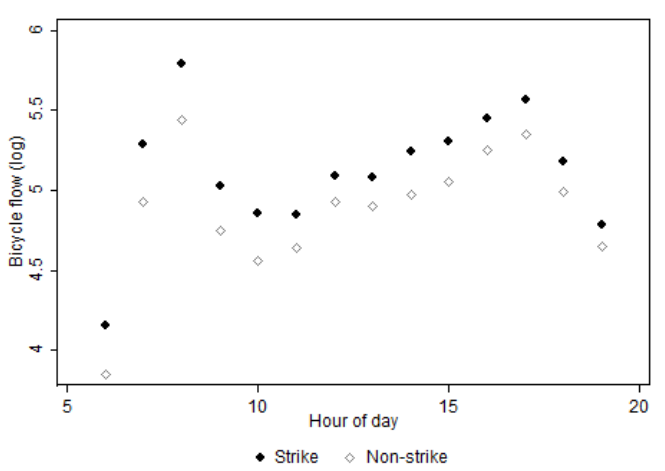

Figure A5 - Speed-flow relationship highway

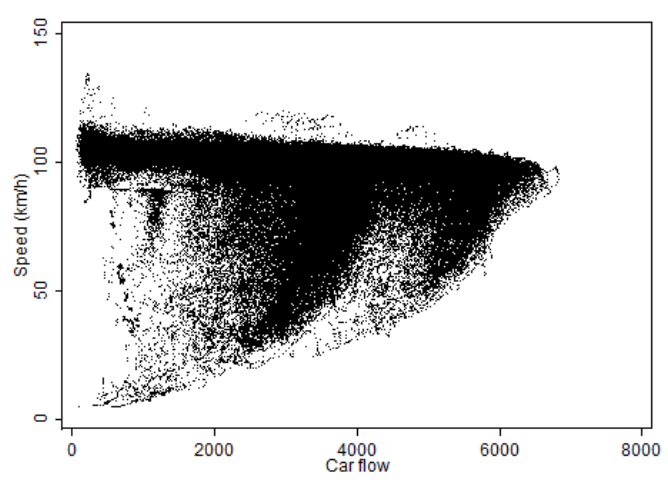


Table A2 - Bicycle flow demand, car demand and car speed on inner city roads

\begin{tabular}{|c|c|c|c|c|c|c|}
\hline \multirow{2}{*}{$\begin{array}{l}\text { Strike mode } \\
\text { Rail strike 21-12-2000 }\end{array}$} & \multicolumn{2}{|c|}{ Car speed (log) } & \multicolumn{2}{|c|}{ Car flow (log) } & \multicolumn{2}{|c|}{ Bicycle flow (log) } \\
\hline & & & 0.108 & $* * *$ & 0.069 & $* *$ \\
\hline & & & $(0.028)$ & & $(0.035)$ & \\
\hline \multirow{2}{*}{ Citywide strike 14-10-2004 } & -0.093 & $* * *$ & 0.126 & *** & 0.510 & $* * *$ \\
\hline & $(0.005)$ & & $(0.013)$ & & $(0.055)$ & \\
\hline \multirow[t]{2}{*}{ Rail strike 17-06-2005 } & 0.011 & $* *$ & 0.059 & *** & -0.055 & $* *$ \\
\hline & $(0.005)$ & & $(0.016)$ & & $(0.022)$ & \\
\hline \multirow[t]{2}{*}{ Citywide strike 29-06-2005 } & -0.196 & $* * *$ & 0.114 & *** & 0.037 & \\
\hline & $(0.018)$ & & $(0.024)$ & & $(0.051)$ & \\
\hline \multirow{2}{*}{ Citywide strike 18-09-2006 } & -0.042 & $* * *$ & 0.091 & $* * *$ & 0.072 & $* *$ \\
\hline & $(0.014)$ & & $(0.018)$ & & $(0.029)$ & \\
\hline \multirow[t]{2}{*}{ Citywide strike 25-09-2006 } & -0.165 & $* * *$ & 0.162 & $* * *$ & 0.167 & *** \\
\hline & $(0.006)$ & & $(0.011)$ & & $(0.032)$ & \\
\hline \multirow[t]{2}{*}{ Citywide strike 16-02-2011 } & -0.001 & & 0.039 & *** & 0.191 & $* * *$ \\
\hline & $(0.009)$ & & $(0.010)$ & & $(0.062)$ & \\
\hline \multirow[t]{2}{*}{ Citywide strike 11-05-2011 } & -0.187 & $* * *$ & 0.144 & *** & 0.250 & $* * *$ \\
\hline & $(0.027)$ & & $(0.014)$ & & $(0.046)$ & \\
\hline \multirow[t]{2}{*}{ Citywide strike 09-06-2011 } & -0.097 & $* * *$ & 0.012 & & 0.306 & *** \\
\hline & $(0.013)$ & & $(0.044)$ & & $(0.030)$ & \\
\hline \multirow[t]{2}{*}{ Citywide strike 08-10-2003 } & 0.004 & & 0.031 & *** & 0.245 & $* * *$ \\
\hline & $(0.007)$ & & $(0.010)$ & & $(0.041)$ & \\
\hline \multirow{2}{*}{ Citywide strike 04-09-2006 } & -0.002 & & -0.028 & $* *$ & -0.019 & \\
\hline & $(0.005)$ & & $(0.012)$ & & $(0.066)$ & \\
\hline \multirow[t]{2}{*}{ Citywide strike 15-11-2006 } & 0.011 & & -0.028 & * & 0.065 & \\
\hline & $(0.016)$ & & $(0.017)$ & & $(0.065)$ & \\
\hline \multirow{2}{*}{ Citywide strike 12-04-2011 } & 0.008 & & 0.060 & **** & 0.022 & \\
\hline & $(0.058$ & & $(0.014)$ & & $(0.032)$ & \\
\hline \multirow[t]{2}{*}{ Citywide strike 29-06-2011 } & -0.022 & & 0.040 & & 0.152 & \\
\hline & $(0.014)$ & & $(0.048)$ & & $(0.084)$ & \\
\hline \multirow[t]{2}{*}{ Citywide strike 20-11-2011 } & 0.005 & & 0.019 & $* *$ & -0.077 & $* * *$ \\
\hline & $(0.002)$ & & $(0.008)$ & & $(0.020)$ & \\
\hline \multirow[t]{2}{*}{ Regional bus strike 20-05-2008 } & 0.010 & & -0.014 & & 0.050 & \\
\hline & $(0.012)$ & & $(0.021)$ & & $(0.057)$ & \\
\hline \multirow[t]{2}{*}{ Regional bus strike 1 21-05-2008 } & -0.114 & $* * *$ & -0.037 & $* *$ & 0.085 & \\
\hline & $(0.013)$ & & $(0.020)$ & & $(0.056)$ & \\
\hline \multirow[t]{2}{*}{ Regional bus strike 22-05-2008 } & -0.058 & $* * *$ & 0.014 & & 0.027 & \\
\hline & $(0.013)$ & & $(0.021)$ & & $(0.056)$ & \\
\hline \multirow[t]{2}{*}{ Placebo Rail 02-04-2001 } & & & 0.024 & & 0.173 & $* * *$ \\
\hline & & & $(0.016)$ & & $(0.020)$ & \\
\hline \multirow[t]{2}{*}{ Placebo Citywide strike 06-10-2009 } & -0.022 & $* * *$ & -0.0227 & * & -0.046 & * \\
\hline & $(0.007)$ & & $(0.0133)$ & & $(0.025)$ & \\
\hline Placebo Citywide strike 06-11-2011 & 0.019 & $* * *$ & -0.007 & $* * *$ & -0.114 & **** \\
\hline & $(0.007)$ & & $(0.008)$ & & $(0.023)$ & \\
\hline Controls & & ded & Inc & & & \\
\hline Number of observations & & & & & & \\
\hline $\mathrm{R}^{2}$ & & & & & & \\
\hline
\end{tabular}

Note: Strike dummies apply for hours when strike is reported. For the 2000 rail and 2001 placebo strike there is no speed information available. See Table 4 for control variables. ${ }^{* *}$, ** indicate 1 and $5 \%$ significance levels. Standard errors are robust and clustered by day. 


\section{References}

Aftabuzzaman, M., Currie, G., \& Sarvi, M. (2010). Evaluating the congestion relief impacts of public transport in monetary terms. Journal of Public Transport, 13(1), 1-24.

Aljanahi, A. A. M., Rhodes, A. H., \& Metcalfe, A. V. (1999). Speed, speed limits and road traffic accidents under free flow conditions. Accident Analysis \& Prevention, 31(1), 161-168.

Anderson, M. L. (2014). Subways, strikes and slowdowns: the impacts of public transit on traffic congestion. Amercian Economic Review, 104(9), 2763-2796.

Arnott, R. (2013). A bathtub model of downtown traffic congestion. Journal of Urban Economics, 76, 110-121.

Basso, L. J. \& Silva, H. E. (2014). Efficiency and substitutability of transit subsidies and other urban transport policies. American Economic Journal: Economic Policy, 6(4), 1-33.

Bell, R. C., \& Vibbert, R. L. (1990). Mathematicl correction of axle undercouting in pneumatic tubes traffic survey. ITE Journal, 60(2).

Card, D. (1990). Strikes and wages: a test of an asymmetric information model. The Quarterly Journal of Economics, 105(3), 625-659.

CBS (2014) Centraal Bureau for de Statistiek. Retrieved on $4^{\text {th }}$ of November 2014 on http://statline.cbs.nl/Statweb/publication/?DM=SLNL\&PA=81127NED\&D1=0$1 \& \mathrm{D} 2=\mathrm{l} \& \mathrm{D} 3=\mathrm{a} \& \mathrm{D} 4=0,38-44 \& \mathrm{D} 5=0 \& \mathrm{D} 6=\mathrm{a} \& \mathrm{VW}=\mathrm{T}$.

Compton, J., \& Pollak, R. A. (2014). Family proximity, childcare, and women's labor force attachment. Journal of Urban Economics, 79, 72-90.

Crain J. L. \& Flynn, S. D. (1975). Southern California rapid transit district 1974 strike impact study. California Department of Transportation, Division of Mass Transportation, Sacramento, CA.

De Vries, C. (2013). Verplaatsingen in Rotterdam, Stadsregio en Nederland, 2004 -2011. Centrum voor Onderzoek en Statistiek (COS).

Fosgerau, M. \& Small, K. A. (2013). Hypercongestion in downtown metropolis. Journal of Urban Economics, 76. 122-134.

Franzosi, R. (1989). One hundred years of strike statistics: methodological and theoretical issues in quantitative strike research. Industrial and Labor Relations Review, 348-362.

Geroliminis, N. \& Daganzo, C. F. (2008). Existence of urban-scale macroscopic fundamental diagrams: Some experimental findings. Transportation Research Part B, 42(9), 759770 .

Graham, D. J. (2007). Variable returns to agglomeration and the effect of road traffic congestion. Journal of Economics, 62(1): 103-20.

Johnson, W. R. (2014). House prices and female labor force participation. Journal of Urban Economics, 82, 1-11.

Kantor, Y., Rietveld, P., \& van Ommeren, J. N. (2014). Towards a general theory of mixed zones: The role of congestion. Journal of Urban Economics, 83, 50-58.

Kok, N., Monkkonen, P., \& Quigley, J. M. (2014). Land use regulations and the value of land and housing: An intra-metropolitan analysis. Journal of Urban Economics, 81, 136148.

Lo, S., \& Hall, R. W. (2006). Effects of the Los Angeles transit strike on highway congestion. Transport Research A, 40, 903-917.

Marsden, G., \& Docherty, I. (2013). Insights on disruptions as opportunities for transport policy change. Transport Research Part A, 51, 46-55.

Mohring, H. (1972). Optimization and Scale Economies in Urban Bus Transportation. American Economic Review, 62, 591-604.Nelson, P., Baglino, A., Harrington, W., Safirova, E. \& Lipman, A. (2007). Transit in Washington, DC: current benefits and optimal level of provision. Journal of Urban Economics, 62(2), 231-251. 
ONS (2014). Retrieved on $24^{\text {th }}$ September 2014 from http://www.statistics.gov.uk/hub/labourmarket/people-in-work/labour-disputes/index.html.

OVPRO (2014). RET maakt 11 miljoen euro winst in 2013. Vakblad vor stads en streekvervoer. Retrieved on $1^{\text {st }}$ November 2014 from http://www.ovpro.nl/bus/2014/05/20/ret-maakt-11-miljoen-euro-winst-in-2013.

Parry, I. W. \& Small, K. A. (2009). Should urban transit subsidies be reduced? The American Economic Review, 99(3), 700-724.

PbIVVS (1984). Effects of Traffic Transportation of a Strike at HTM [in Dutch], Main report, Projectbuerau Integrale Verkeers en Vervoerstudies. Ministrie van Verkeer and Waterstaat, The Hague.

Proost, S. \& Van Dender, K. (2008). Optimal urban transport pricing in the presence of congestion, economies of density and costly public funds. Transportation Research Part A: Policy and Practice, 42(9): 1220-1230.

Proost, S. (2014). Pricing of public transit under union power. Presented at: International Transportation Economics Association Conference, 2014.

Savelberg, F. (Ed.). (2013). Mobiliteitsbalans 2013. Kennisinstituut voor Mobiliteitsbeleid.

Small, K. A. \& Verhoef, E. (2007). The economics of urban transport. Routledge.

Snelder, M. (2010). Designing robust road networks: a general design method applied to the Netherlands. TU Delft.

Stadsregio Rotterdam (2012). $€ 227$ miljoen subsidie voor het OV. Retrieved on $24^{\text {th }}$ of September 2014 from http://stadsregio.nl/\%E2\%82\%AC-227-miljoen-subsidie-voorhet-ov.

The Economist, (2000). Bused up, the LA transport strike, The Economist, print edition, September $23^{\text {rd }} 2000$.

Thomas, T., Jaarsma, R., \& Tutert, B. (2013). Exploring temporal fluctuations of daily bicycle travel demand on Dutch cycle paths: the influence of weather on bicycle travel. Transport, 40(1), 1-22.

Treinreiziger (2011). Staking RET al om 9 uur begonnen. (Retrieved on $18^{\text {th }}$ of February 2014 from http://www.treinreiziger.nl/actueel/binnenland/staking_ret_al_om_9_uur_ begonnen-14535)

van der Loop, J. T. A. (1997). Intermodality: Successes by integrating modes and cycling. Public transport planning and operations. Proceedings of seminar $\mathrm{G}$ held at the European transport forum, 416, Brunel University.

van Exel, N.J.A. \& Rietveld, P. (2001). Public transport strikes and traveler behavior, Transport Polic, 8, 237-243.

van Exel, N.J.A. \& Rietveld, P. (2009). When strikes come to town, Transport Research Part A, 43, 526-525.

van Goeverden, C. D., \& Egeter, B. (1993). Gecombinieerd gebruik van fiets en openbaar vervoer: verwachte effecten op de vervoerwijzekeuze van optimale fietsbeschikbaarbeid in voor- en natransport. Technische Universiteit Delft, Faculteit der Civiele Techniek, Vakgroup Verkeer.

Vukovic, D., Adler, M. W. \& Vonk, T. (2013). Neerslag en Verkeer. TNO. 